\title{
Problematika Remaja dalam Mengikuti Bimbingan Keagamaan
}

\author{
Gia Sugiantoro Fauzan ${ }^{1 *}$, Lilis Satriah ${ }^{2}$, Luk-luk Atin Marfuah ${ }^{2}$ \\ ${ }^{1}$ Bank Negara Indonesia \\ ${ }^{2} J u r u s a n$ Bimbingan dan Konseling Islam, UIN Sunan Gunung Djati, Bandung \\ *Email:giasugiantoro@gmail.com
}

\begin{abstract}
ABSTRAK
Penelitian ini untuk mengetahui kondisi bimbingan keagamaan Islam, kondisi remaja dan hambatan-hambatan yang terjadi pada remaja sehingga para remaja kurang tertarik dalam mengikuti kegiatan bimbingan keagamaan di RW 07 Desa Langonsari. Metode yang digunakan dalam penelitian ini adalah metode deskriptif kualitatif, dengan tujuan untuk mengungkap fenomena yang berkenaan dengan problematika remaja dalam mengikuti bimbingan keagamaan. Hasil penelitian menunjukan bahwa tidak tersedia kegiatan bimbingan Agama untuk remaja yang disebabkan kurang tertariknya para remaja. Ada beberapa hambatan yang terjadi pada remaja, sehingga membuat para remaja tidak aktif dalam kegiatan bimbingan keagamaan, yakni: malas, kurang motivasi, malu, sibuk, jadwal tidak sesuai, tidak tahu ada bimbingan agama dan kegiatan kurang menarik. Pemecahan masalah dari hambatan yang terjadi yaitu dengan mengadakan perkumpulan remaja untuk mengaktifkan lagi kegiatan-kegiatan remaja.
\end{abstract}

Kata Kunci : Problematika; Remaja; Bimbingan Keagamaan.

\section{ABSTRACT}

This research is to find out the condition of Islamic religious guidance, to know the condition of adolescents and to know the obstacles that occur in adolescents so that adolescents less interested in participating in religious guidance activities in $\mathrm{RW} 07$ Langonsari Village. The method used in this study is a qualitative descriptive method, with the aim of uncovering phenomena related to adolescent problems in following religious guidance. The results of the study that are not available religious guidance activities for adolescents due to lack of interest in adolescents. There are several obstacles that occur in adolescents, so as to make teens inactive in religious guidance activities: laziness, lack of motivation, shame, busy, schedule is not appropriate, do not know there is religious guidance, and less interesting activities. Solving the problem of obstacles that occur is by bolding a youth association to reactivate youth activities.

Keywords : Problematics; Teenagers; Religious Guidance. 


\section{PENDAHULUAN}

Remaja merupakan proses perkembangan manusia sebelum beranjak menuju dewasa. Pada perkembangan manusia ada beberapa tahapan yang harus dilalui, di mulai dari fase balita saat usia 0-5 tahun, fase anak-anak saat usia 6-11 tahun, fase remaja saat usia 12-23 tahun, fase dewasa saat usia 24-49 tahun, dan fase lansia saat usia manusia melebihi usia 50 tahun. Pada tahap perkembangan, manusia memiliki tugas perkembangannya agar tumbuh dengan baik. Pada fase remaja terdapat beberapa fase, fase-fase dalam remaja, yaitu: (1) fase remaja awal 12-15 tahun, (2) fase remaja menengah 15-18 tahun, (3) fase remaja akhir 18-23 tahun. Di masa remaja, manusia memiliki rasa penasaran atau keinginan untuk mencoba hal-hal baru yang belum mereka lakukan termasuk sesuatu hal yang bertentangan. Untuk itu mereka sangat memerlukan komunikasi, keteladanan, serta konsistensi yang tulus dari orang dewasa agar para remaja terarah kemana kemauan serta pemikirannya dan tidak tersesat pada fase mencari jati dirinya.

Fase remaja adalah masa transisi dari anak-anak ke dewasa. Pada fase ini, remaja sudah mulai banyak berfikiran ke masa depan dan banyak terpengaruh oleh lingkungan. Banyak yang akan mempengaruhi baik itu hal yang positif maupun yang negative. Mencari kesibukan dengan mengikuti kegiatan-kegiatan baik adalah hal positif yang sudah sering dilakukan oleh remaja, tidak hanya itu bahkan ada juga kegiatan yang menjerumuskan remaja kepada yang negative. Oleh karena itu sangat penting untuk membimbing remaja karena remaja merupakan generasi penerus yang harus siap mengemban misi kemanusian di lingkungan.

Perkembangan zaman saat ini yang semakin pesat, membuat para remaja terkena imbas dari perkembangan zaman. Banyak remaja yang terpengaruh oleh lingkungan yang negative, namun tidak sedikit pula remaja yang terpengaruh oleh lingkungan positive. Karena perkembangan zaman inilah banyak remaja yang kurang ilmu pengetahuan tentang agama bahkan tidak sedikit pula yang tidak mengenal agamanya padahal mereka menganut agama itu sendiri. Ada beberapa factor yang mempengaruhi kurangnya ilmu pengetahuan agama pada remaja seperti kesadaran orang tua dalam mendidik anak sehingga perkembangan pada anak itu terpengaruhi. Tidak hanya itu factor pertemanan juga mempengaruhi perkembangan remaja, seperti jika seorang remaja bergaul dengan orang baik maka remaja tersebut akan terbawa baik dan sebaliknya jika remaja tersebut bergaul dengan yang tidak baik maka remaja tersebut akan terbawa kepada hal yang tidak baik. Kurangnya kesadaran beragama pada remaja membuat kegiatan bimbingan agama yang sering dilakukan di banyak tempat hanya dipenuhi oleh orang tua saja, sedangkan remaja jarang mengikuti kegiatan bimbingan agama

Untuk menyelamatkan generasi muda, para remaja perlu di bimbing dan dibina agar mampu menghadapi kehidupan yang lebih baik untuk dirinya dan lingkungan. Bimbingan keagamaan merupakan kegiatan yang dilakukan seseorang 
dalam rangka memberikan bantuan kepada orang lain yang mengalami kesulitankesulitan rohaniyah dalam lingkungan hidupnya agar orang tersebut mampu mengatasi permasalahan atau problematikanya sendiri karena timbul kesadaran atau penyerahan diri terhadap kekuasaan Tuhan.

Dewasa ini, kegiatan bimbingan agama untuk remaja sering kita jumpai di berbagai kegiatan, seperti pengajian remaja di majelis ta'lim, kajian yang di hadiri remaja, bimbingan membaca Al-Qur'an pada remaja, dan banyak lagi. Namun, dengan banyaknya kegiatan bimbingan agama yang tersedia, tidak sedikit pula remaja pada saat ini kurang berminat untuk mengikuti bimbingan keagamaan. Kurang berminatnya remaja mengikuti bimbingan keagamaan memunculkan problem-problem atau masalah-masalah yang membuat remaja kurang berminat mengikuti bimbingan keagamaan. Oleh sebab itu, penulis terdorong untuk melakukan penelitian berjudul "Problematika Remaja dalam Mengikuti Bimbingan Keagamaan" yang berlokasi di RW 07 Desa Langonsari Kecamatan Pameungpeuk Kabupaten Bandung.

Penelitian ini berlandaskan pada penelitian sebelumnya oleh Eneng Kurniawati (2018) yang berjudul "Bimbingan Keagamaan Terhadap Remaja Geng Motor di Kelurahan Cipadung Kota Bandung". Penelitian ini bertujuan untuk mengubah pola pikir remaja yang mengikuti geng motor agar para remaja yang mengikuti geng motor bisa lebih paham dengan kegiatan-kegiatan yang positif. Substansi yang penulis pahami dari hasil penelitian tersebut, bahwa dengan adanya kegiatan bimbingan agama para remaja bisa mengaplikasikan materi-materi bimbingan yang sudah di terapkan dan di pelajari, serta para remaja bisa mematuhi norma-norma sosial maupun agama. Di lihat dari hasil penelitian tersebut, maka penulis tertarik untuk mencari tahu problem-problem atau masalah-masalah yang dialami oleh remaja sehingga para remaja tidak tertarik mengikuti kegiatan bimbingan keagamaan. Padahal setelah dilihat bahwa kegiatan bimbingan keagamaan bisa mengubah pola pikir remaja agar bisa lebih paham dengan kegiatan-kegiatan yang positif.

Selanjutnya, penelitian oleh Lies Hamidah (2018) yang berjudul "Bimbingan keagamaan untuk meningkatkan kesadaran beragama pada remaja di Masjid AlLatif bertempat di Jl. Saninten No. 2 Kota Bandung 40114”. Penelitian ini bertujuan untuk meningkatkan kesadaran beragama bagi para remaja. Substansi yang penulis pahami dari hasil penelitian tersebut, bahwa banyak remaja yang mulai mengikuti kegiatan pemuda hijrah dari berbagai kalangan. Kalangan yang banyak mengikuti kegiatan pemuda hijrah kebanyakan berasal dari mantan anggota geng motor, anak jalanan. Dari penelitian itu bisa kita lihat bahwa bimbingan agama bisa merubah pola pikir remaja dan bimbingan agama pula bisa meningkatkan kesadaran beragama bagi remaja. Maka dari itu, saya berharap dari penelitian yang akan penulis angkat, penulis bisa mengetahui masalah atau 
hambatan remaja dalam mengikuti bimbingan keagamaan, karena bimbingan agama remaja sangat penting untuk meningkatkan kesadaran beragama pada remaja.

Perbedaan penelitian ini dengan penelitian terdahulu, penelitian ini menggunakan metode deskriptif dengan pendekatan kualitatif dengan fokus pada mencari hambatan-hambatan dan masalah-masalah yang dialami oleh remaja sehingga para remaja kurang tertarik dalam mengikuti kegiatan bimbingan keagamaan.

Penelitian yang di teliti oleh penulis dilakukan pada remaja di RW 07 Desa Langonsari, Kecamatan Pameungpeuk, Kabupaten Bandung. Dengan alasan tersedianya data yang akan di tentukan sebagai objek penelitian dan karena di lokasi ini mempunyai permasalahan untuk di teliti serta mempermudah pencarian data. Metode yang digunakan dalam penelitian ini yatu menggunakan metode deskriptif kualitatif. Alasan menggunakan metode deskriptif kualitatif yaitu untuk mengungkap fenomena yang berkenaan dengan problematika remaja dalam mengikuti bimbingan keagamaan dengan harapan peneliti bisa mengetahui hambatan-hambatan atau masalah yang terjadi pada remaja sehingga para remaja kurang berminat untuk mengikuti kegiatan bimbingan keagamaan.

\section{LANDASAN TEORITIS}

Remaja merupakan proses peralihan dari fase anak-anak menuju pada fase dewasa, pada masa ini remaja sering dilanda kebingungan untuk memilih, dan kebingungan untuk memilih merupakan permasalahan yang terjadi. Fase remaja merupakan segmen perkembngan yang sangat penting, diwalai dengan matangnya organ-organ fisik sehingga mampu bereporduksi. (Kinanti: 2019)

Kata remaja berasal dari bahasa latin, yaitu adolescere yang artinya "tumbuh". Orang terdahulu memandang masa puber dan masa remaja tidak berbeda dengan periode lain dalam rentang kehidupan. Anak dianggap sudah dewasa apabila sudah pada masa reproduksi. Istilah adolescence sesungguhnya memiliki arti luas, mencakup kematangan mental, emosional, social, dan fisik. Pandangan ini didukung oleh Piaget yang mengatakan bahwa "secara psikologis, remaja adalah suatu usia pada individu menjadi integrasi kedalam masyarakat dewasa." (Mohammad Ali, dkk 2014:9).

Masa remaja adalah masa yang penuh dengan tantangan untuk melatih kemampuan dalam penyelesaian permasalahan-permasalahan yang terjadi dalam kehidupan secara nyata dan mengembangkan karakter yang ada pada dirinya. (Al Afgani: 2018)

Sukardi (2016:16) mengatakan masa remaja adalah masa peralihan dari masa anak-anak ke masa dewasa yang ditandai dengan kematangan seksual, gejolak emosi dan tekanan jiwa sehingga mudah menyimpang dari aturan dan norma. Sependapat dengan itu Willis berpendapat bahwa "Remaja merupakan masa 
peralihan dari masa anak-anak menuju ke masa dewasa yang mencakup kepada kematangan mental, emosional, sosial dan fisik manusia.” (Willis, S. S. 2017: 19).

Penyebab utama sikap keras dalam masalah agama remaja adalah lingkungan kemasyarakatan. Wajib diadakan pengarahan agama bagi para remaja mulai dari usia remaja awal hingga masa usia remaja akhir. Karena pada jenjang usia ini, mereka berada dalam kondisi yang penuh keraguan dan ketidakjelasan. Kurangnya pendidikan dan pengetahuan agama untuk menumbuhkan kesadaran diri pada remaja merupakan runtuhnya moral dikalangan remaja. Dalam halkeadaan diri pada masa remaja, para remaja mengalami perubahan-perubahan yang dramatis, dalam kesadaran diri mereka (self-awareness). Mereka sangat rentan terhadap pandapat orang lain karena mereka menganggap bahwa orang lain selalu mengkritik mereka, seperti mereka mengkritik diri mereka sendiri. Anggapan itu membuat remaja sangat memperhatikan diri mereka dan citra yang diperlihatkan (self image).

Banyak remaja menyelidiki agama sebagai suatu sumber rangsangan emosional dan intelektual. Para pemuda ingin mempelajari agama berdasarkan pengertian intelektual dan tidak ingin menerima begitu saja. "Mereka meragukan agama bukan karena ingin menjadi agnostik atau atheis, melainkan karena mereka ingin menerima agama sebagai sesuatu yang bermakna berdasarkan keinginan mereka untuk mandiri dan bebas menentukan keputusan mereka sendiri” (Hurlock, 1980: 222).

Problematika berasal dari bahasa Inggris, yaitu "Problematic" yang artinya masalah atau persoalan. Problematika sering terjadi dalam kehidupan umat manusia. Adapun masalah itu sendiri adalah suatu persoalan yang harus dipecahkan, dengan kata lain masalah merupakan kesenjangan antara kenyataan dengan suatu yang diharapkan dengan baik, agar tercapai hasil yang di inginkan. Problema berasal dari berbagai persoalan-persoalan sulit yang dihadapi dalam proses pemberdayaan, problema sendiri bisa terjadi dari individunya sendiri (factor internal) ataupun bawaan dari luar individu (faktor eksternal). Problematika adalah suatu kesenjangan antara harapan dan kenyataan yang diharapkan dapat menyelesaikan atau dapat di perlukan atau dengan kata lain dapat mengurangi kesenjangan itu. Pada masa remaja banyak sekali problematika yang dihadapi. Problem itu datang dari diri remajanya ataupun dari lingkungan remajanya. Di dalam jurnalnya, Krisphiyanti mengatakan bahwa "semakin remaja tidak dapat menyelesaikan permasalahan yang terjadi pada diri mereka, maka semakin berkembang pula rasa egois pada diri remaja" (Krisphiyanti, 2017: 24)

Bimbingan Agama merupakan kegiatan yang dilakukan oleh seseorang pembimbing dalam rangka memberikan bantuan kepada orang lain yang mengalami kesulitan-kesulitan rohaniah dalam lingkungan hidupnya supaya orang tersebut mampu mengatasinya sendiri karena timbul kesadaran atau 
penyerahan diri terhadap kekuasaan Allah SWT. Sehingga timbul pada diri pribadinya suatu cahaya harapan kebahagiaan hidup saat sekarang dan masa depannya. Dalam hal ini Bimbingan Agama Islam berarti sebuah bimbingan tidak menentukan atau mengharuskan, melainkan sekedar membantu individu agar dapat hidup selaras dengan ketentuan dan petunjuk Allah. Bimbingan juga bisa disebut dengan irsyad. "Irsyad Islam berarti proses pemberian bantuan kepada diri sendiri (irsyad nafsiyah), individu (irsyad fardiyah) dan kelompok kecil (irsyad fiah qalilah) agar dapat keluar dari berbagai kesulitan”. (Arifin: 2008)

Bimbingan keagamaan pada dasarnya merupakan kegiatan pada kehidupan manusia kenyataan menunjukan bahwa manusia dalam kehidupannya sering menghadapi segala persoalan, dalam menghadapi persoalan-persoalan manusia disinilah fungsi bimbingan keagamaan yang berperan dalam mengatasi persoalan tersebut. Sependapat dengan itu faqih mengatakan bahwa "Bimbingan Islam adalah proses pemberian bantuan kepada individu agar mampu hidup selaras dengan ketentuan dan petunjuk Allah, sehingga dapat mencapai kebahagiaan hidup didunia dan akhirat" (Faqih, A. R. 2001:4).

Menurut Arifin bimbingan keagamaan merupakan suatu proses pemberian pelayanan atau bantuan kepada peserta bimbingan dengan memperhatikan kemungkinan-kemungkinan dan kenyataan tentang adanya kesulitan yang dihadapi peserta bimbingan dalam rangka mengembangkan pribadinya secara optimal, sehingga peserta bimbingan memahami tentang dirinya, mengarahkan diri, serta bersikap sesuai dengan tuntutan keadaan lingkungan, keluarga, dan masyarakat. Bantuan yang diberikan dengan caracara yang efektif yang bersumber pada ajaran serta nilai-nilai agama yang ada pada diri pribadinya (H.M. Arifin, 1994:7)

Bimbingan agama Islam dalam rangka membantu individu terutama peserta didik tentu memiliki tujuan agar peserta didik dapat mengenal kelebihan dan kelemahan dirinya sendiri serta menerimanya secara positif sebagai modal pengembangan diri lebih lanjut. Menurut Faqih (2001: 36), terdapat 2 tujuan kegiatan bimbingan agama. Tujuan bimbingan agama yang pertama adalah tujuan umum yang mencakup kepada Membantu individu mewujudkan dirinya menjadi manusia seutuhnya agar mencapai kebahagiaan di dunia dan di akhirat. Dan tujuan kedua ialah tujuan khusus yang mencakup kepada Membantu individu mengatasi masalah, serta membantu individu mewujudkan dirinya menjadi manusia seutuhnya agar mencapai kebahagiaan dunia dan akhirat

Pembimbing merupakan seseorang yang melakukan kegiatan bimbingan. Sebagai seorang pembimbing atau konselor harus memiliki beberapa kriteria agar pesan bimbingan bisa diterima oleh yang terbimbing. Kritria itu mencakup kepada dapat dipercaya, jujur, peka, memahami diri sendiri, responsive, sabar, terbuka.

Terbimbing atau biasa disebut dengan klien atau mad'u merupakan individu yang menerima kegiatan bimbingan keagamaan. Sesuai dengan fungsi bimbingan, 
maka klien atau mad'u dalam kegiatan bimbingan tidak mesti individu yang mempunyai atau menghadapi masalah, hal ini berbeda dengan konseling yang kliennya adalah individu yang mempunyai masalah. Materi bimbingan merupakan bantuan yang diberikan oleh pembimbing kepada jamaah. Menurut Abudin, "Materi akhlak yang diberikan mencakup: bertingkah baik dengan cara meninggikan rasa bersyukur kepada Allah, saling menyayangi, sikap toleransi sesama manusia, tidak merusak keindahan alam" (Abuddin, 2012:149)

Metode merupakan suatu cara yang digunakan untuk melakukan sesuatu. Menurut Amin (2010: 69) menyebutkan bahwa "metode bimbingan secara umum antara lain: metode wawancara (interview), Bimbingan kelompok (Group Guidance), metode yang dipusatkan pada keadaan klien, metode pencerahan, dan metode psikoanalisis" (Amin, 2010: 69). Metode bimbingan agama Islam tidak jauh berbeda dengan metode dakwah, sehingga metode bimbingan agama Islam dapat pula dikatakan sama dengan metode dakwah. Metode tersebut sudah terjelaskan di dalam Al-Qur'an yaitu yang terkandung dalam surat An-Nahl: 125

"Serulah (manusia) kepada jalan Tuhan-mu dengan hikmah dan pelajaran yang baik dan bantahlah mereka dengan cara yang baik. Sesungguhnya Tuhanmu Dialah yang lebih mengetahui tentang siapa yang tersesat dari jalan-Nya dan Dialah yang lebih mengetahui orang-orang yang mendapat petunjuk". (Depag RI, 2005: 383)

Seperti halnya komunikasi, banyak sekali media yang dapat dipergunakan untuk mengefektifkan prosesnya. Seperti halnya komunikasi masa yang mempergunakan media atau alat dalam mengaplikasikan atau menyampaikan komunikasi, begitu pula dengan bimbingan yang melihat dari kemajuan zaman yang serba instan dan cepat ini melalui teknologi komunikasi yang semakin canggih. Sebab itu, yang dimaksud dengan media adalah alat bantu yang menunjang keberlangsungan proses bimbingan. "Perkembangan media yang semakin memperkaya mutu dengan muatan edukasi untuk masyarakat, dapat dipelajari melelui pengalaman hidup seseorang" (Enjang 2009: 47).

Ada beberapa kegiatan bimbingan agama untuk remaja. Agar bimbingan agama remaja bisa berjalan dengan baik, maka kita bisa memimilih materi dan metode yang cocok untuk remaja. Materi yang biasa disampaikan oleh pembimbing agama mencakup kepada Akhlak, Aqidah, Fiqh, membahas fenomena keislaman yang terjadi. Tidak hanya pemilihan materi, pemilihan metode juga sangat penting untuk kegiatan bimbingan agama remaja. Pemilihan metode bimbingan agama remaja sangat penting supaya kegiatan bimbingan agama untuk remaja bervariasi dan remaja tidak cepat bosan. Menurut Sukardi (2016) mengatakan bahwa, Bimbingan agama di kalangan remaja, menuntut para pembimbing untuk mencari metode bimbingan yang sesuai dengan kondisi remaja tersebut diantaranya: tanya jawab, dikusi, keteladanan, penggunaan sarana 
teknologi secara optimal, serta melalui penyaluran bakat dan minat remaja" (Akhmad Sukardi, 2016).

\section{HASIL DAN PEMBAHASAN}

RW 07 merupakan bagian dari 15 RW yang ada di Desa Langonsari Kecamatan Pameungpeuk Kabupaten Bandung. RW 07 mempunyai luas wilayah kurang lebih 31.295m2 yang terdapat jumlah Rukun Tetangga (RT) sebanyak 5 (lima) RT yang penduduknya berjumlah 430 jiwa dengan jumlah kepala keluarga sebanyak 208 KK dengan jumlah remaja sebanyak 42 orang. Dengan beragam jenis, kebiasaan, agama, dan pekerjaan yang berbeda dari setiap anggota individunya. Pemukiman warga RW 07 tertata rapih karena RW 07 sudah termasuk perumahan. Letak tempat RW 07 berada dekat dengan wisata Kampung Batu dan Montain Brezze. Selain itu, RW 07 juga berdekatan dengan Kecamatan Baleendah Kabupaten Bandung.

Sarana dan prasarana yang terdapat di RW 07 yaitu tersedia sarana kesehatan, pendidikan, keamanan dan keagamaan. Kondisi pendidikan di RW 07 untuk saat ini tergolong baik. Masyarakat terutama remaja dan anak-anak mempunyai keinginan untuk bersekolah sehingga tidak ada remaja dan anak-anak yang putus sekolah. Kondisi keagamaan di RW 07 terdapat dua agama yang hidup rukun berdampingan, yaitu agama Islam dan Kristen. Mayoritas masyarakat RW 07 memeluk agama Islam dengan jumlah pemeluk 414 dan 16 orang yang memeluk agaman Kristen.

\section{Kondisi Objektif Bimbingan Agama Islam Remaja}

Kondisi bimbingan agama di RW 07, tersedia program bimbingan untuk masyarakat RW 07. Tidak hanya untuk RW 07 saja, kegiatan bimbingan agama juga terbuka untuk warga-warga sekitar RW 07. Kegiatan bimbingan agama Islam yang tersedia ialah pengajian bapak-bapak, pengajian ibu-ibu, pengajian remaja, dan pengajian anak-anak, serta khusus untuk remaja ditambahkan dengan kegiatan berupa diskusi mengenai keIslaman serta fenomena-fenomena yang terjadi. Kegiatan tersebut sudah sering dilakukan dan terjadwalkan setiap Minggunya. Jadwal, jam serta tempat dilakukannya kegiatan bimbingan agama Islam yang telah tersedia dapat dilihat pada table 1. 
Tabel 1.

Jadwal Kegiatan Bimbingan Agama

\begin{tabular}{llll}
\hline Nama Kegiatan & Jadwal & Waktu & Tempat \\
\hline $\begin{array}{l}\text { Pengajian Ibu- } \\
\text { ibu }\end{array}$ & Senin dan Kamis & Pukul 15.00-17.00 & $\begin{array}{l}\text { Majelis Ta'lim } \\
\text { Baiturahman }\end{array}$ \\
$\begin{array}{l}\text { Pengajian Bapak- } \\
\text { bapak }\end{array}$ & Selasa dan & Ba'da Isya-20.30 & $\begin{array}{l}\text { Majelis Ta'lim } \\
\text { Baiturahman }\end{array}$ \\
$\begin{array}{l}\text { Pengajian } \\
\text { Remaja }\end{array}$ & Sabtu & Ba'da Isya-20.30 & $\begin{array}{l}\text { Majelis Ta'lim } \\
\text { Baiturahman }\end{array}$ \\
$\begin{array}{l}\text { Pengajian Anak- } \\
\text { anak }\end{array}$ & Senin-Jumat & Ba'da Ashar-17.00 & $\begin{array}{l}\text { Majelis Ta'lim } \\
\text { Baiturahman }\end{array}$ \\
\hline
\end{tabular}

Sumber: Hasil wawancara penelitian

Tabel 1. tersebut adalah jadwal untuk kegiatan bimbingan agama yang dilaksanakan setiap minggunya oleh masyarakat RW 07 Desa Langonsari. Namun seiring dengan jalannya waktu, yang masih aktif melakukan kegiatan bimbingan agama ialah pengajian bapak-bapak, pengajian ibu-ibu, dan pengajian anak-anak. Pengajian remaja menjadi tidak aktif, di sebabkan banyak remaja yang mulai sibuk dengan urusannya dan banyak remaja yang sudah tidak tertarik mengikuti kegiatan bimbingan agama.

Bimbingan keagamaan adalah usaha pemberian bantuan kepada seseorang yang kesulitan baik lahiriyah maupun bathiniyah yang menyangkut kehidupan masa lampau, masa kini dan masa yang akan datang. Bantuan yang diberikan berupa pertolongan spiritual dan mental agar orang yang bersangkutan mampu mengatasinya dengan kemampuan dirinya sendiri melalui dorongan dari kekuatan iman dan taqwa kepada Tuhannya. Menurut Enjang, "bimbingan keagamaan adalah pesan-pesan, materi atau segala sesuatu yang harus disampaikan oleh kiyai kepada santri, yaitu keseluruhan ajaran Islam, yang ada di dalam kitab Allah maupun sunah Rasul-Nya". (Enjang AS, Aliyudin, 2009:80 yang dikutip dari Anshari, 1993:146).

Sesuai dengan itu bimbingan agama di RW 07 dilaksanakan oleh pembimbing agar bisa membantu masyarakat mengembangkan fitrah hidupnya dengan ajaran yang ada di Al-Qur'an dan Hadits. Sehingga yang tersedia di dalam teori sangat serupa dengan fakta di lapangan yang mengatakan bahwa bimbingan agama Islam merupakan materi yang disampaikan yang terkandung dalam AlQur'an dan Hadits. Menurut analisis penulis, kegiatan bimbingan agama Islam yang di lakukan di RW 07 sudah sangat baik, karena sudah sesuai dengan teori yang disampaikan dan dengan adanya kegiatan bimbingan agama Islam dapat membantu masyarakat dalam mengembangkan fitrah hidupnya. 
Tujuan dilaksanakannya bimbingan agama di RW 07 antara lain untuk meningkatkan kesadaran beragama, meningkatkan pengetahuan agama untuk warga RW 07 serta masyarakat sekitar dan mampu memberi pengetahuan baru untuk masyarakat agar dapat memahami tentang agama yang mereka yakini. Hasil dari wawancara dengan pembimbing agama, dia mengatakan tujuan dilakukan bimbingan agama setiap minggu kepada masyarakat di RW 07 antara lain untuk memberikan pemahaman tentang keagamaan Islam, selain itu dari pengajian diharapkan ibu-ibu, bapak-bapak, remaja, dan anak-anak bisa membaca Al-Qur'an dan secara tidak langsung dengan adanya kegiatan itu bisa menghatam kan AlQur'an dan memahami isi kandungan Al-Qur'an. Selain membaca Al-Qur'an, dalam kegiatan pengajian ini bisa memberikan pemahaman tentang keIslaman.

Menurut Faqih (2001: 36), terdapat 2 tujuan kegiatan bimbingan agama. Tujuan bimbingan agama yang pertama adalah tujuan umum yang mencakup kepada Membantu individu mewujudkan dirinya menjadi manusia seutuhnya agar mencapai kebahagiaan di dunia dan di akhirat. Dan tujuan kedua ialah tujuan khusus yang mencakup kepada Membantu individu mengatasi masalah, serta membantu individu mewujudkan dirinya menjadi manusia seutuhnya agar mencapai kebahagiaan dunia dan akhirat. (Faqih, 2001: 36)

Serupa dengan itu tujuan dilaksanakannya bimbingan agama di RW 07 antara lain untuk meningkatkan kesadaran beragama, meningkatkan pengetahuan agama untuk warga RW 07 dan mampu memberi pengetahuan baru untuk masyarakat agar dapat memahami tentang agama yang mereka yakini. Karena setelah masyarakat memahami tentang agama yang di yakini, masyarakat akan mendapatkan kebahagiaan di dunia dan di akhirat, selain itu masyarakat juga mendapatkan pengetahuan baru dari kegiatan bimbingan agama. Menurut analisis penulis tujuan dari kegiatan bimbingan agama Islam yang tersedia di RW 07 sudah sesuai dengan teori dari ahli. Karena dengan adanya bimbingan agama Islam, masyarakat bisa mendapatkan ilmu yang baru agar selamat dan bahagia di dunia dan di akhirat.

Fungsi kegiatan bimbingan agama di RW 07 adalah untuk mencegah masyarakat berbuat hal-hal yang melanggar norma dan hukum serta menjauhkan masyarakat dari hal-hal yang negative. Pemeliharaan dan pengembangan agar kondisi masyarakat yang baik menjadi tetap baik dan lebih baik lagi. Dengan adanya kegiatan dan pembelajaran di bimbingan agama membuat masyarakat khususnya remaja mendapatkan pemahaman dan kegiatan yang positif untuk dilakukan oleh remaja.

Menurut Faqih (2001: 37), "fungsi kegiatan bimbingan agama yaitu untuk: (1) Pencegahan timbulnya masalah bagi klien; (2) Penyembuhan untuk klien yang memiliki masalah; (3) Pemeliharaan agar yang baik tetap baik; (4) Pengembangan, Penyaluran, Pengadaptasian dan Penyesuaian kemampuan yang dimiliki klien". 
(Faqih, 2001: 37)

Sependapat dengan itu fungsi bimbingan agama di RW 07 yaitu untuk mencegah masyarakat berbuat hal-hal yang melanggar norma dan hukum serta menjauhkan masyarakat dari hal-hal yang negative. Pemeliharaan dan pengembangan agar kondisi masyarakat yang baik menjadi tetap baik dan lebih baik lagi. Dengan adanya kegiatan dan pembelajaran di bimbingan agama membuat masyarakat khususnya remaja mendapatkan pemahaman yang lebih dan kegiatan yang positif.

Menurut Analisis penulis dilihat dari bimbingan agama Islam yang tersedia, tujuan bimbingan agama yang ditujukan, serta fungsi bimbingan agama yang ada di RW 07 Desa Langonsari sudah sesuai dengan teori-teori dari pendapat para ahli. Akan tetapi, walaupun sudah sesuai dengan teori tetap saja kegiatan bimbingan agama untuk remaja di RW 07 tidak berjalan dengan baik, di sebabkan terdapat beberapa faktor yang membuat para remaja kurang tertarik dalam mengikuti kegiatan bimbingan agama Islam di RW 07.

Unsur-unsur bimbingan agama merupakan hal paling penting dalam melakukan kegiatan bimbingan agama agar kegiatan bimbingan agama berjalan lancar unsur-unsur bimbingan agama mencakup kepada pembimbing, terbimbing, materi, media, dan metode.

Pembimbing merupakan seseorang yang melakukan bantuan kepada yang terbimbing. Kegiatan bimbingan agama terasa belum lengkap dan sempurna jika tidak tersedianya pembimbing agama. Di RW 07 sendiri, terdapat beberapa pembimbing agama yang ditugaskan dan di percaya untuk membantu masyarakat dalam memelihara kerukunan masyarakat, serta mengatasi masalah yang dialami oleh masyarakat.

Hasil dari wawancara dengan pembimbing agama, Dia mengatakan terdapat delapan pembimbing, termasuk saya. Dari delapan orang pembimbing itu dibagibagi untuk kegiatan bimbingannya, empat pembimbing untuk kegiatan bimbingan ibu-ibu dan bapak-bapak, dua pembimbing untuk kegiatan bimbingan remaja, dan dua pembimbing untuk kegiatan bimbingan anak-anak. Pembimbing yang ada disini dipilih karena masyarakat sudah percaya terhadap kita untuk melakukan kegiatan bimbingan keagamaan. Saya di percaya oleh DKM untuk mejadi pembimbing agama remaja, karena menurut DKM saya selalu aktif mengikuti kegiatan bimbingan agama dan percaya kepada saya untuk melakukan kegiatan bimbingan agama pada remaja. (Sumber wawancara dengan pembimbing agama)

Pembimbing merupakan seseorang yang melakukan bantuan kepada yang terbimbing. Menurut Yusuf (2006: 37) terdapat beberapa persyaratan yang harus dimiliki pembimbing atau konselor, persyaratannya yaitu: Memiliki pemahaman diri, Kompeten, Memiliki kesehatan psikologis, Dapat dipercaya, Jujur, Kuat, Responsive, Sabar, Peka, Memiliki kesadaran yang kholistik 
Dilihat dari teori tersebut, pembimbing agama yang tersedia di RW 07 ini belum memenuhi persyaratan pembimbing, hanya saja pembimbing agama di RW 07 sudah di percaya oleh masyarakat untuk membimbing masyarakat dalam kegiatan bimbingan agama.

Terbimbing merupakan individu atau kelompok yang mendapatkan kegiatan bimbingan. Masyarakat di RW 07 berhak mengikuti dan menerima bimbingan agama agar menjadikan masyarakat yang mengerti tentang agama yang diyakini dan menghidari kegiatan yang salah.

Menurut hasil wawancara dengan Pembimbing agama, Dia mengatakan bahwa kegiatan bimbingan agama di RW 07 ini di peruntukan untuk semua kalangan, tidak hanya untuk RW 07 saja, namun bila ada yang mau ikut serta walaupun bukan dari RW 07 kami sangat terbuka. Karena menurutnya setiap masyarakat berhak mengikuti kegiatan keagamaan yang ada, baik itu bapak-bapak, ibu-ibu, remaja, sampai anak-anak. Sudah tersedia jadwal setiap minggunya untuk kegiatan bimbingan agama. Saya harap dengan adanya kegiatan ini masyarakat bisa mengikutinya dengan baik. (sumber wawancara dengan Pembimbing Agama)

Menurut Musnamar (1992:146) menjelaskan bahwa yang menjadi objek garapan dari bimbingan keagamaan adalah Upaya mencegah dan atau mengatasi masalah yang berkaitan dengan ketidakberagaman, kesulitan memilih agama, kegoyahan iman (kekufuran), konflik pandanganatau wawasan keagamaan, kekurangfahaman mengenai syariat Islam, dan ketidakmauan dan ketidakmampuan menjalankan syariat Islam dengan baik dan benar.

Sesuai dengan teori tersebut, dan dilihat dari tujuan bimbingan keagamaan di RW 07, maka terdapat kesesuaian antara teori dan fakta dilapangan. Karena tujuan utama di adakan kegiatan bimbingan keagamaan agar menjadikan masyarakat mengerti tentang agama yang diyakini dan menghidari kegiatan yang salah.

Metode merupakan cara penyampaian pesan yang dilakukan oleh pembimbing kepada yang terbimbing. Menurut hasil wawancara dengan pembimbing agama, didapatkan bahwa para pembimbing agama di RW 07 menggunakan beberapa metode yang dilakukan untuk kegiatan bimbingan agama ini dan berbeda setiap usia nya. Metode yang digunakan merupakan metode membaca Al-Qur'an, ceramah, Tanya jawab dan diskusi mengenai keIslaman. Dari hasil wawancara dengan pembimbing, dia mengatakan bahwa metode yang digunakan adalah metode ceramah, diskusi dengan masyarakat tentang keIslaman, dan membaca Al-Qur'an. (Sumber wawancara dengan pembimbing agama)

Metode merupakan cara yang dilakukan pembimbing untuk menjalankan kegiatan bimbingan agama. Menurut (Willis 2017:33-34) ada beberapa metode untuk melakukan kegiatan bimbingan agama. Metode yang diberikan agar kegiatan bimbingan agama Islam tidak membosankan untuk remaja adalah: Ceramah, 
Tanya jawab, dikusi, dan keteladanan.

Sesuai dengan itu, dari hasil dari wawancara dengan pembimbing agama, di dapatkan bahwa metode yang digunakan oleh pembimbing agama di RW 07 sesuai dengan teori yang ada, karena metode yang digunakan ialah metode ceramah, Tanya jawab, diskusi dengan masyarakat tentang keIslaman, dan membaca AlQur'an. Maka, di lihat dari hasil itu ditemukan bahwa metode yang digunakan oleh pembimbing agama di RW 07 sudah sesuai dengan teori yang ada.

Materi merupakan pesan yang disampaikan atau ucapan yang disampaikan oleh pembimbing agama kepada yang terbimbing. Hasil dari wawancara dengan pembimbing agama di ketahui bahwa materi yang disampaikan oleh pembimbing agama di RW 07 untuk kegiatan bimbingan agama mencakup kepada: Ibadah, Fiqh, Akhlak, Tauhid, Aqidah, Membahas fenomena-fenomena yang terjadi. (Sumber wawancara dengan pembimbing agama)

Materi merupakan ucapan yang disampaikan oleh pembimbing agama. Materi bimbingan agama Islam merujuk pada tiga aspek, yaitu bimbingan Aqidah, Akhlak, dan Syariah.

Materi bimbingan aqidah merupakan materi yang selalu dibawakan oleh pembimbing, karena aqidah merupakan suatu pondasi Islam. Unsur paling penting dari aqidah adalah keyakinan mutlak bahwa Allah itu Esa dan tidak terbilang (Rahmat, 1994: 24)

Materi bimbingan syariah meliputi berbagai hal tentang keIslaman yaitu yang berkaitan dengan aspek ibadah dan muamalah. Prayitno mengungkapkan bahwa 'bimbingan mu'amalah membantu jamaah mengenal dan berhubungan dengan lingkungan sosialnya yang dilandasi dengan budi pekerti luhur, tanggung jawab kemasyarakatan dan kenegaraan". (Prayitno, 1997: 66)

Sesuai dengan itu, hasil wawancara dengan pembimbing agama di RW 07, dia mengatakan materi yang disampaikan oleh pembimbing agama di RW 07 untuk kegiatan bimbingan agama mencakup kepada Ibadah, Membaca Al-Qur'an, Ilmu Tauhid, Aqidah, Akhlak, Ilmu Fiqh serta membahas fenomena-fenomena keIslaman yang terjadi. Dilihat dari hasil penelitian serta teori, maka dapat disimpulkan bahwa materi yang disampaikan oleh pembimbing agama di RW 07 sudah sesuai dengan teori yang ada.

Hasil dari penelitian dan wawancara kepada ketua RW, dia mengatakan bahwa terdapat sebanyak 42 orang remaja di RW 07 Desa Langonsari yang terdiri dari 24 remaja Laki-laki dan 18 remaja Perempuan. Dia juga menyebutkan bahwa kondisi remaja di RW 07 ini sangat baik. Dalam 3 tahun belakangan ini, sudah tidak terdengar perilaku-perilaku yang menyimpang dan perilaku negative dari remaja. Sudah tidak terdengar keluhan dari masyarakat tentang perkelahian remaja, remaja mengkonsumsi miras, remaja ikut-ikutan geng motor, hamil sebelum 
menikah dan penangkapan oleh polisi karena remaja mengkonsumsi obat-obatan terlarang atau membuat resah masyarakat.

Namun dari kondisi yang baik ini, banyak orang tua yang menyebutkan bahwa para remaja saat ini lebih senang berdiam diri dibalakang layar computer, laptop, ataupun smartphone untuk bermain video game. Karena faktor itu remaja saat ini kurang bersosialisasi dengan masyarakat. Kegiatan sosial yang dilakukan oleh remaja hanya di lakukan di sekolahnya saja ataupun di tempat kerjanya, setelah selesai, para remaja pulang dan berdiam diri di rumah. Sudah jarang remaja yang mengikuti kegiatan-kegiatan yang disediakan untuk remaja, sebagai contoh karang taruna jadi kurang aktif, ikatan remaja masjid sudah kurang aktif di sebabkan remaja saat ini lebih banyak dan lebih suka berdiam diri di rumahnya sambil bermain video game mereka. (Sumber wawancara dengan Ketua RW). Hal tersebut sependapat dengan teori yang di kutip oleh Sarwono (2001:9), yang mengatakan "masa remaja adalah masa saat terjadi peralihan dari ketergantungan sosial yang penuh kepada keadaan yang relative lebih mandiri”.

Dapat disimpulkan bahwa teori yang di kutip oleh Sarwono, bisa dirasakan oleh para remaja di RW 07 yang sudah berkurangnya ketergantungan bersosial remaja. Remaja di RW 07 lebih memilih menyendiri di rumahnya masing-masing dan bermain game serta media sosial. Atau juga para remaja lebih memilih untuk berdiam di warung internet untuk bermain game. Kesadaran beragama pada remaja di RW 07 yang menjadi PR untuk para pembimbing agama yang ada, karena kesadaran agama pada remaja di RW 07 sudah mulai berkurang, dilihat dari kegiatan-kegiatan bimbingan agama yang sudah mulai sepi. Tidak hanya kesadaran beragamanya saja, namun kesadaran sosialnya juga sudah mulai pudar.

Menurut hasil dari wawancara dengan pembimbing agama, dia mengatakan kalo kesadaran remaja dalam beragama di sini itu sudah mulai pudar. Sekarang remaja sudah acuh terhadap kegiatan keagamaan yang ada. Alhamdulilah masih ada beberapa agama yang sadar dalam beragama seperti pada saat adzan, ada beberapa remaja yang menyempatkan ikut sholat berjamaah, walaupun setelah beres sholat mereka langsung pulang ke rumahnya. Mungkin hanya perlu di kembangkan lagi kesadaran beragamanya, jadi tidak hanya untuk ikut sholat berjamaah lagi, tapi mengaktifkan lagi kegiatan-kegiatan remaja seperti pengajian remaja. (Sumber wawancara dengan pembimbing agama)

Menurut Darajat (1991: 91-106) bahwa sikap remaja terhadap agama terdapat beberapa sikap. Sikap-sikap tersebut ialah: Percaya ikut-ikutan, Percaya dengan kesadaran, Kebimbangan beragama dan Tidak percaya pada Tuhan.

Kesadaran Agama remaja di RW 07 di sesuaikan dari hasil wawancara dan teori terdapat kesesuaian. Kesesuaian tersebut bisa di lihat karena remaja di RW 07 banyak yang ikut-ikutan dalam segala hal, contohnya ketika teman-temannya tidak mengikuti kegiatan bimbingan maka dia juga tidak ikut kegiatan itu. Ataupun ketika temannya ikut dalam kegiatan maka dia juga akan ikut dalam kegiatan 
Dilihat dari hasil penelitian dan wawancara diatas, dapat disimpulkan bahwa kondisi remaja di RW 07 pada saat ini sudah baik. Hal tersebut di lihat dari sudah tidak ada kabar-kabar negatif dari remaja di RW 07. Hanya saja kesadaran sosial remaja di RW 07 masih kurang. Hal tersebut di sebabkan oleh kesibukan yang di alami oleh remaja. Kemajuan teknologi juga berpengaruh terhadap kesadaran sosial remaja karena remaja lebih sering bermain dengan gadget dan media sosialnya, sehingga membuat remaja lebih aktif di media sosial daripada di kehidupan nyata.

\section{Hambatan-Hambatan Remaja dalam Mengikuti Bimbingan Keagamaan}

Setelah melaksanakan penelitian dan wawancara kepada remaja yang kurang tertarik dalam mengikuti kegiatan bimbingan agama, dapat di ketahui bahwa alasan atau hambatan-hambatan yang para remaja rasakan yaitu:

Tabel 2

Hambatan-hambatan yang dialami remaja

\begin{tabular}{ll}
\hline Hambatan & Jumlah \\
\hline Malas & 12 Orang \\
Tidak Ada Teman & 13 Orang \\
Tidak Ada Pendorong Remaja & 2 Orang \\
Malu & 3 Orang \\
Sibuk & 18 Orang \\
Jadwal Tidak Sesuai Dengan Waktu Luang Remaja & 18 Orang \\
Tidak Tahu Ada Kegiatan Bimbingan Agama & 5 Orang \\
Tidak Ada Motivasi & 1 Orang \\
Kegiatan Kurang Menarik & 10 Orang \\
\hline
\end{tabular}

Sumber: Hasil wawancara penelitian

Dari hambatan diatas, hambatan atau problem yang dialami oleh remaja sehingga kurang minat untuk mengikuti kegiatan bimbingan agama ialah problem dari diri sendiri (internal) dan problem dari luar atau lingkungan (eksternal). Darajat (1991: 126-127) menyebutkan bahwa problem yang terjadi pada remaja salah satunya adalah pergaulan dengan teman sebaya. Karena, pada masa remaja tingkat pengaruh teman sebaya kepada kehidupan remaja meningkat. Remaja akan merasa sangat sedih bila di kucilkan dari kelompok teman-temannya. Karena itu ia meniru lagak-lugu, pakaian, sikap, dan tindakan teman-temannya dalam satu 
kelompok.

Setiana (2015: 16-17) menambahkan bahwa terjadinya problem bisa diakibatkan oleh faktor dari dalam individu dan faktor dari luar atau lingkungan. Senada dengan itu, Hasan Basri (1995: 34-35) menyebutkan bahwa "Lingkungan merupakan faktor terpenting yang mempengaruhi prilaku manusia, maka untuk menciptakan generasi yang baik kita harus menciptakan lingkungan yang baik dengan cara lebih banyak berkumpul dan bergaul dengan orang-orang yang sholeh".

Sesuai dengan teori tersebut, hambatan yang terjadi pada remaja di RW 07 dalam mengikuti bimbingan keagamaan ialah pergaulan dengan teman, sehingga membuat remaja kurang tertarik dalam mengikuti kegiatan bimbingan agama karena remaja merasa teman-temannya tidak mengikuti kegiatan bimbingan agama dan remaja juga ikut-ikutan tidak ikut kegiatan bimbingan agama di RW 07. Hambatan yang dialami oleh para remaja RW 07 Desa Langonsari juga terdapat dari faktor dari dalam dan pengaruh dari luar remaja tersebut. Dari situlah alasanalasan remaja kurang tertarik mengikuti bimbingan agama, karena remaja berfikir bahwa tidak ada teman yang ikut kegiatan bimbingan.

\section{Pemecahan Masalah untuk Mengatasi Problematika Remaja}

Pembimbing agama dan DKM, serta jajaran RW sudah berupaya untuk mengatasi kurang minatnya remaja dalam mengikuti bimbingan keagamaan. Cara yang di gunakan untuk mengatasi kurang minatnya remaja adalah dengan mengadakan bimbingan agama remaja yang disatukan dengan orang tua, membuat pertemuan remaja untuk membahas kegiatan-kegiatan remaja di RW 07 seperti mengaktifkan lagi karang taruna, PIK-R, remaja masjid, dan pengajian remaja, serta menjadwalkan ulang kegiatan bimbingan keagamaan remaja.

Menurut Willis (2017: 139) upaya untuk mengatasi problematika remaja yaitu dengan mengisi waktu luang remaja dengan kegiatan positif yang bersifat kepada keterampilan berorganisasi, seperti membuat organisasi taruna karya, organisasi remaja yang independen, organisasi olahraga, dll.

Sudarsono (1995: 125-126) menambahkan "Orang tua hendaknya memberikan kesibukan dan mempercayakan sebagai tanggung jawab kepada si remaja”. Pendapat itu senada dengan pendapat Sarwono (2002: 207) yang menyebutkan bahwa "keluarga merupakan faktor terpenting dalam perkembangan remaja". Sesuai dengan teori tersebut, upaya pemecahan masalah untuk mengatasi problematika remaja dalam mengikuti bimbingan keagamaan di RW 07 yang telah dilaksanakan ialah dengan mengadakan bimbingan agama remaja yang disatukan dengan orang tua, membuat pertemuan remaja untuk membahas kegiatankegiatan remaja di RW 07 seperti mengaktifkan lagi karang taruna, PIK-R, remaja masjid, dan pengajian remaja, serta menjadwalkan ulang kegiatan bimbingan keagamaan remaja. 


\section{PENUTUP}

Kondisi objektif bimbingan agama di RW 07 Desa Langonsari, tersedia sarana dan prasarana untuk kegiatan keislaman atau kegiatan bimbingan agama Islam. Di RW 07 Desa Langonsari, terdapat kegiatan bimbingan agama untuk bapak-bapak, ibuibu, remaja, dan anak-anak. Tujuan dari kegiatan bimbingan agama adalah untuk meningkatkan kesadaran beragama, meningkatkan pengetahuan agama untuk masyarakat RW 07 Desa Langonsari. Kegiatan bimbingan agama sering berjalan dan diadakan setiap minggunya, dengan beberapa tahapan, yaitu: Tahapan pertama merupakan tahap pembentukan, tahap kedua merupakan tahap kegiatan, tahap ketiga merupakan tahap akhir, kesimpulan dan evaluasi. Hanya saja kegiatan bimbingan agama untuk remaja tidak berjalan dengan baik di karenakan faktor remaja yang mengikuti bimbingan agama sudah banyak yang tidak menghadiri kegiatan tersebut, sehingga membuat bimbingan agama remaja tidak berjalan baik.

Kondisi objektif remaja RW 07 Desa Langonsari pada saat ini sudah tidak ada kabar-kabar negatif dari remaja di RW 07 Desa Langonsari. Hanya saja kesadaran sosial remaja dan kesadaran beragama remaja di RW 07 Desa Langonsari banyak yang masih kurang sadar keagamaannya. Hal tersebut di sebabkan oleh kesibukan yang di alami oleh remaja serta banyak remaja yang mengikuti teman-temannya. Kemajuan teknologi juga berpengaruh terhadap kesadaran sosial remaja karena remaja lebih sering bermain dengan gadget dan media sosialnya, sehingga membuat remaja lebih aktif di media sosial daripada di kehidupan nyata.

Ada beberapa hambatan yang terjadi pada remaja di RW 07 Desa Langonsari dalam mengikuti kegiatan bimbingan agama Islam. Penyebab atau hambatan remaja kurang tertarik dalam kegiatan bimbingan agama di Rw 07 Desa Langonsari ialah: (1) Malas, (2) Tidak ada teman, (3) Tidak ada pendorong remaja, (4) Malu, (5) Sibuk, (6) Jadwal tidak sesuai dengan waktu luang remaja, (7) Tidak tahu ada bimbingan agama, (9) Tidak ada motivasi, dan (10) Kegiatan Kurang Menarik. Tersedia beberapa cara yang dilakukan oleh pembimbing agama, DKM, serta jajaran RW agar remaja mengikuti kegiatan bimbingan agama. Cara yang dilakukan adalah dengan menyatukan kegiatan bimbingan agama remaja dengan orang tua, membuat pertemuan remaja untuk mengaktifkan remaja, serta menjadwalkan ulang kegiatan bimbingan keagamaan remaja di RW 07 Desa Langonsari.

\section{DAFTAR PUSTAKA}

Al Afgani, J. (2018). Pemberdayaan Remaja Muslim melalui Program Akademi Berdaya Kreatif, Anida (Aktualisasi Nuansa Ilmu Dakwab). Vol. 18. No. (1), $61-84$.

Ali, M., dkk. (2014). Metodologi dan Aplikasi Riset Pendidikan. Jakarta: Bumi Aksara 
G. S. Fauzan., L. Satriah., L. A. Marfu'ah

Amin, S. M. (2010). Bimbingan dan Konseling Islam. Jakarta: AMZAH.

Arifin, H.M. (1994). Ilmu Pendidikam Islam: Suatu Tinjanan Teoritis dan Praktis Berdasarkan Pendekatan Interdisipliner. Jakarta: Bumi Aksara.

Arifin, I. Z. (2008). Bimbingan dan Konseling Islam (Al-Irsyad Wa Altawjîh AlIslam) Berbasis Ilmu Dakwah, Ilmu Dakwah: Academic Journal for Homiletic Studies. Vol. 4. No. (11), 27-42

Aunur R. F. (2001). Bimbingan Dan Konseling Dalam Islam. Yogyakarta: UII Press.

Basri, H. (1995). Remaja Berkualitas. Pustaka Pelajar. Yogyakarta.

Darajat, Z. (1991). Ilmu Jiwa Agama, Jakarta: Bulan Bintang.

DEPAG R.I. (2005). Al Quran Terjemah Indonesia. PT Sari Agung, Jakarta.

Enjang. A S. (2009). Komunikasi Konseling. Bandung: NUANSA.

Hamidah, L. (2018). Bimbingan Keagamaan untuk Meningkatkan Kesadaran Beragama Remaja. Skripsi. UIN Sunan Gunung Djati Bandung.

Hurlock, E. B. (1980). Psikologi Perkembangan. Jakarta: Erlangga.

Kinanti, R. D. (2019). Peranan Bimbingan Keagamaan dalam Meningkatkan Kecerdasan Spiritual Remaja, Irsyad: Jurnal Bimbingan, Penyuluban, Konseling, dan Psikoterapi Islam. Vol. 7. No. (2), 233-252.

Krisphianti, Y. D. (2017). Peran Komponen Program Bimbingan Konseling (Layanan yang Ditawarkan untuk Membantu Problematika Remaja. Prosiding Seminar Nasional Bimbingan dan Konseling. Vol. 1 (1), 19-27.

Kurniawati, E. (2018). Bimbingan Keagamaan Terbadap Remaja Geng Motor di Keluraban Cipadung Kota Bandung. Skripsi. UIN Sunan Gunung Djati Bandung.

Nata, A.. (2012). Pemikiran Pendidikan Islam dan Barat. Jakarta: PT. Raja Grafindo Persada.

Prayitno. (1997). Pelayanan Bimbingan dan Konseling (SLTP). Jakarta: PT. Bina Sumber Daya MIPA.

Sarwono, S. W. (2001). Psikologi Remaja. Jakarta: Raja Grafindo Persada.

Sarwono, S. W. (2002). Psikologi Sosial. Jakarta: Balai Pustaka

Setiana, W. (2015). Patologi Sosial. Bandung: CV. Mimbar Pustaka

Sofyan S. W. (2017). Remaja dan Masalahnya Mengupas Berbagai bentuk Kenakalan Remaja Seperti Narkoba, Freesex dan Pemecahannya. Bandung: CV Alfabeta.

Sudarsono. (1995). Kenakalan Remaja. Jakarta: Rineka Cipta

Sukardi, A. (2016). Metode Dakwah dalam Mengatasi Problematika Remaja, AlMunzir. Vol. 9. No. 1, 13-28.

Tohari, M. (1992). Dasar-Dasar Konseptual Bimbingan Dan Konseling Islami. Jakarta: UII Press.

Yusuf, S. dan Nurihsan, J. (2005). Landasan Bimbingan dan Konseling. Bandung: Rosda Karya. 